\title{
HOME SCHOOLING: INDIAN PERSPECTIVE
}

\author{
Gururaj $\mathrm{P}^{1}$ 四 (1) \\ ${ }^{1}$ Faculty, Department of Commerce, Mangalore University, Mangalore, Dakshina Kannada, India
}
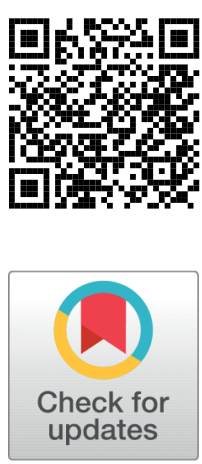

\section{ABSTRACT}

Homeschooling is a subject of great fascination, but little solid knowledge. Despite its importance, it has received less research attention than some other recent changes in the educational system, such as the growth of charter schools. It could be argued that home schooling may have a much larger impact on educational system, both in the short and long run. Despite the fact that some people are against the homeschooling scheme, most developing nations have introduced it and made it legal. In this study a small attempt has been made to understand the concept of homeschooling and its view in Indian perspective. Homeschooling is not commonly used in India, but it has increased in popularity in recent years. Homeschooling is often confused with online education in India. Homeschooling is not connected with e-learning or online learning. As per the RTE Act there is no scope for Homeschooling in India, so there is a need of certain amendments in the Act.

Received 17 April 2021

Accepted 3 May 2021

Published 31 May 2021

Corresponding Author

Gururaj P, gururajp224@gmail.co

$\mathrm{m}$

DOI $10.29121 /$

granthaalayah.v9.i5.2021.3897

Funding: This research received no specific grant from any funding agency in the public, commercial, or not-for-profit sectors.

Copyright: (C) 2021 The Author(s). This is an open access article distributed under the terms of the Creative Commons Attribution License, which permits unrestricted use, distribution, and reproduction in any medium, provided the original author and source are credited.

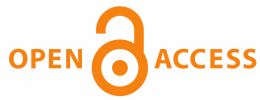

Keywords: Homeschooling, Online Learning Educational System

\section{INTRODUCTION}

"The idea is to educate, not follow anyone's schedule about when something should be studied." - Ray Drouillard

Homeschooling is a social movement that is spreading around the country and across the world; it is an academic alternative that lets in mother and father to educate their kids at domestic as opposed to sending them to school Crhe-The (2021). Homeschooling is an excellent way to put the school and everything associated with it directly into the child's household. Parents will take on the position of teacher at home, and school will assist them in meeting the educational needs of their children Live (2020). Homeschooling is an alternative educational system to private and public schools. Families chose to homeschool for a number of factors, some parents have concerns about the social environment or academic quality of local public schools including disappointment with educational opportunities, differing theological or educational beliefs, and the perception that children are not improving within 
the standard school system Martin (2020).

\subsection{HISTORY}

The homeschooling movement gained traction in the 1970s, when well-known writers and scholars such as John Holt, Dorothy and Raymond Moore, and others began writing about educational reform Lynn (2019). The conventional homeschool movement started in the 1970s, when John Holt, an educational activist and school reform advocate, argued that formal schools' emphasis on rote learning provided an authoritarian classroom atmosphere intended to turn children into obedient workers. Holt urged parents to free their children from formal education. Eventually after Holt's theories encouraged the first homeschoolers, Holt's friend educational scholar Raymond Moore chimed in, suggesting that early schooling was harmful to children and that children should be schooled at home until the age of eight or nine in order to provide them with a solid educational, social, and spiritual base Crhe-The (2021). In the United States, there are an estimated 4.0 to 5.0 million homeschool students in grades $\mathrm{K}-12$ (or $7 \%$ to $9 \%$ of school-age children). In the spring of 2019 , there were about 2.5 million homeschool students (or 3\% to $4 \%$ of school-age children). The homeschool population has been expanding at a rate of 2 to $8 \%$ each year for many years, but it increased significantly from 2019-2020 to 2020-2021 Ray et al. (2021).

\section{GROWTH OF HOMESCHOOLING IN THE UNITED STATES}

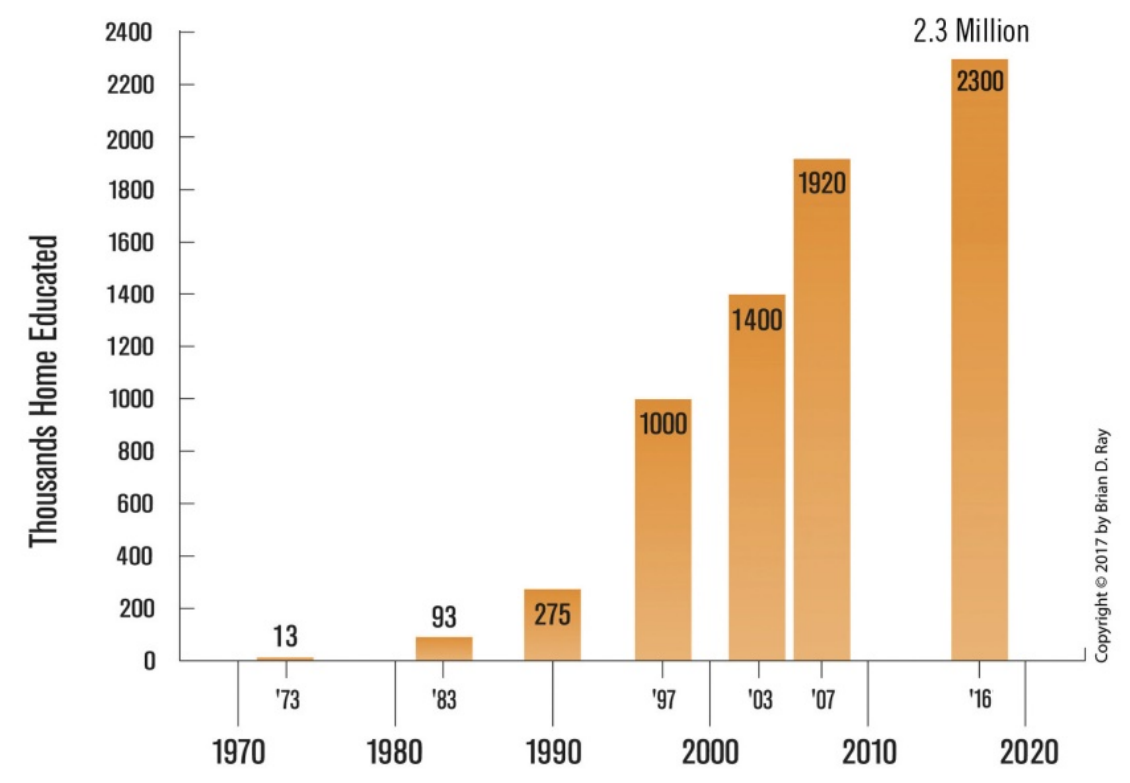

\section{REVIEW OF LITERATURE}

Homeschooling is increasingly common in developed countries, but it is also gaining popularity in many developing countries. Parent-led home-based schooling is fundamentally distinct from institutional public and private schools in terms of education 
paradigm, climate, and experience. The new homeschool trend and culture demonstrates that it is very popular educationally and socially for homeschooled children and adults Ray and Ray (2013).For a number of causes, these parents preferred to educate their children at home, and they have both pedagogical and ideological opposition to public schooling. Many homeschoolers are inspired by their own adverse educational experiences or by an urge to improve or maintain the nuclear family's solidarity, to live an alternative lifestyle, and/or to affirm their right to decide their children's education Arai (2000).Many parents choose homeschooling to guarantee that their children received an inexpensive, good education. Furthermore, parents needed to ensure that each child had an individualized experience, which is especially important for children with special needs Dlamini et al. (2021). Academic and socialization results for the average homeschooled pupil outperform those of the average public school student Basham (2007). Parents only choose to homeschool after many attempts to work with the public school and mothers bore the main weight of responsibility for homeschooling in the families. While the transition to homeschooling alleviated many of the problems that these families faced in public school, it also introduced new difficulties Jolly et al. (2016). Most parents found it difficult to strike the right balance between their roles as parents and teachers. Furthermore, a significant obstacle was identified as a lack of government funding. As a result, it advises lawmakers as well as the government to take a more complex and integrated approach Dlamini et al. (2021).Parents were unhappy with the assistance services provided for their child's educational and psychological needs. Parents feel incompetent and unprepared, and they assumed that their child's schooling and mental health would suffer as a result of his or her absence from school. Parents also spoke of the damaging effects of homeschooling on their and their families' wellbeing Greenway and Eaton-Thomas (2020). Most parents found it difficult to strike the right balance between their roles as parents and teachers. Furthermore, a significant obstacle was identified as a lack of government funding. As a result, it advises lawmakers as well as the government to take a more complex and integrated approach Homeschooling is a suitable and successful method of teaching children. How nations and organizations help homeschooling families has a strong effect on the sustainability of home education and its effectiveness. The HOME acronym summarizes four ways a community should promote homeschooling. To begin, authorities will support home educators by $(\mathrm{H})$ helping families in finding their match. They will do this by assisting and empowering families to tailor their educational methods to the specific needs of each child. Following that, a community should assist homeschooling families by (0) offering a wide variety of teaching services. This can provide technical and educational choices. Third, nations should embrace homeschooling by (M) making it socially appropriate. The unfounded stigmas that sometimes afflict homeschoolers can be alleviated by accepting and educating the public of the benefits of this activity. Finally, through (E) empowering homeschool alliances, a community will open more doors for the formation of hybrid homeschool organizations and associations. 
This will result in more success in the homeschooling environment Kumar and Rao (2019)

\section{HOME SCHOOLING IN INDIA}

Homeschooling is not widely practiced in India, but it has grown in significantly in recent years in major cities such as Bangalore, Pune, and Mumbai. Homeschooling is not currently governed by any governmental department. As a result, homeschoolers are not required to file with the current government departments or authorities. Homeschoolers tend to follow the CBSEC curriculum or the state curriculum HSLDA (2019) After the passage of the Right of Children to Free and Compulsory Education Act (RTE), which renders formal education a fundamental right of any child between the ages of 6 and 14 and sets minimum norms for colleges, educators, politicians, and parents have discussed the legality of homeschooling in India and a multitude of alternative education schools spread throughout various states. Although the validity of homeschooling is still debatable, there have been petitions filed in the past by parents and alternative schools seeking relief SCHOOL (2010).

In India, the concept of homeschooling often gets confused with online schooling. Homeschooling is not the same as e-learning or online learning via school or multinational educational technology company, during the COVID-19 pandemic. The online platforms such as BYJU's, Unacademy, Vedantu, Toppr and Doubtnut are some of the example for online schooling or educational technology companies, where expert will assist the students with the help of their parents. Homeschooling is where parents make the deliberate decision not to take their children to school and instead teach them at home. Although no set curriculum or pedagogy is practiced, parents and students collaborate together to create a versatile syllabus based on their inspiration.

In India, since homeschooling is not included as one of the meanings of "school" in the RTE Act, it follows that homeschooling would not be recognized by the government.so; homeschoolers felt that the RTE Act violated their right to choose their form of education. As a result, homeschoolers requested that the act be amended to include homeschooling as one of the permitted modes of education. HSLDA (2019)

\subsection{ADVANTAGES AND DISADVANTAGES}

Parents who wish to homeschool their children but have any questions should think of the pro's and con's of homeschooling. Parents have the opportunity to Determine the curriculum and their children's schooling schedule and they can demonstrate to their children that education is fun and so that they can create a good relationship with their children. Apart from that they can spend extra time with their children it will help their children to develop any special talent that they possess Loveless (2021). As every bright side has a darker counterpart. Homeschooling does have several drawbacks. Home schooling parents are required to be around their children 
all day long. This can be difficult when children become restless and misbehave and parents have to spend large amounts of money on books and other learning materials it can also lead to frustrations in kids as they can't enjoy school and make new friends. This can sometimes make kids go into depression as they have no or minimal interactions outside their home. There is a chance of Irregular learning because parents have personal interests that prohibit them from attending normal teaching sessions and also if parents do not have a broad understanding of all subjects, they will struggle to teach them all Arora (2018).

\subsection{HOMESCHOOLING VS ONLINE SCHOOL}

Despite the distinctions between homeschooling and online education, many people use both words interchangeably. It's understandable to be perplexed. After all, they both encourage students to learn outside of a traditional school setting. In homeschooling, parents serve as full-time educators, while in online education, also known as virtual learning, online teachers administer students' studies from a distance through a structured programme. In homeschooling the concerned programme is purchased or built by parents, who often act as instructors. Where as in online school Parents (or any designated adult) use a programme developed by an existing virtual school to act as learning coaches in addition to hired instructors. Religion is not allowed to influence the instruction in public online colleges but in homeschooling Faith-based education can be included. Socialization experiences must be created by the parent themselves whereas many online schools incorporate tools for socialization into their curriculum. Few states mandate homeschooled children to be assessed, although others do not but in online schooling the state standardized examinations are administered by public online schools Bartolone et al. (2018).

\section{CONCLUSION}

Parents nowadays are more educated than before. They hold the capability to teach their kids the values and lessons taught at school. With this, the idea of educating children at home has also gained momentum .There are now a plethora of services and opportunities open to homeschooling families, and in an era of growing school choice, homeschooling is becoming increasingly embraced by the general public. Homeschooling is a method of educating children in a school environment but still under the supervision and care of their parents. It is up to the parents to determine what the children should study and how it should be instructed, while staying within the bounds of one of the educational boards that rule the region.

Parents today are more prepared than in the past. They have the opportunity to instill in their children the values and lessons learned in school. As a result, the concept of homeschooling children has gained traction. There is no knowledge about homeschooling, and the government has refused to clear any facts on homeschooling. But the problem is that the government has changed its position on homeschooling 
in the past and is shifting its stance again. They do not promote homeschooling constitutionally, so if anyone wants to homeschool his or her children, the government will not intervene or act against them.

\section{REFERENCES}

Arai, A. B. (2000). Reasons for Home Schooling in Canada. Canadian Journal of Education / Revue canadienne de l'éducation, 25(3), 204-204. Retrieved from https://dx.doi.org/ $10.2307 / 1585954$ 10.2307/1585954

Arora, M. (2018). Homeschooling in India - Pros and Cons. [Blog post]. Retrieved from https://parenting.firstcry.com/articles/homeschooling-benefits-and-downsides/

Bartolone, G., Homeschooling, \& Vs. (2018). Homeschooling vs. Online School: What's the Difference? [Blog post]. Retrieved from https://s.niche.com/homeschooling-vs-online -school-whats-the-difference/

Basham, P. (2007). Home Schooling: From the Extreme to the Mainstream. The Fraser Institute.

Crhe-The. (2021). Coalition for Responsible Home Education. An Introduction to Homeschooling. Boston: The Coalition for Responsible Home Education.

Dlamini, N., Maharaj, P., \& Dunn, S. (2021). Home-schooling in South Africa: Adapting to the new normal of providing education. Perspectives in Education(1), 39-39.

Greenway, C. W., \& Eaton-Thomas, K. (2020). Parent experiences of home-schooling children with special educational needs or disabilities during the coronavirus pandemic. British Journal of Special Education, 47(4), 510-535. Retrieved from https://dx.doi.org/ 10.1111/1467-8578.12341 10.1111/1467-8578.12341

HSLDA. (2019). HSLDA. Legal status and resources on homeschooling in India. 07. Retrieved from <https://hslda.org/post/india>

Jolly, J. L., Matthews, M. S., \& Nester, J. (2016). Homeschooling the Gifted : A Parent 's Perspective. SAGE Journals. Retrieved from https://journals.sagepub.com/doi/10.1177/ 0016986212469999 https://doi.org/10.1177/0016986212469999

Kumar, D. E. G., \& Rao, D. E. S. (2019). Histopathology vs fine needle aspiration cytology in determining thyroid swellings. International Journal of Clinical and Diagnostic Pathology, 2(2), 334-337. Retrieved from https://dx.doi.org/10.33545/pathol.2019.v2.i2e .123 https://doi.org/10.33545/pathol.2019.v2.i2e.123

Live, E. (2020). Here's how My Chhota School's homeschool brings convenient education to your doorstep. Retrieved from https://www.edexlive.com/news/2020/jun/30/ heres-how-my-chhota-schools-homeschool-brings-convenient-education-to-your -doorstep-12976.html\#: :text=Instead\%20of\%20making\%20the\%20process,the\% 20child\%20in\%20doing\%20that

Loveless, B. (2021). Benefits and Disadvantages of Homeschooling. [Blog post]. Retrieved from https://www.educationcorner.com/benefits-disadvantages-of-homeschooling .html

Lynn, S. (2019, october 3). A Brief History of Homeschooling. [Blog post]. Retrieved from https://greathomeschoolconventions.com/blog/a-brief-history-of-homeschooling

Martin, J. (2020). Retrieved from https://www.parents.com/.26April2021<https:// www.parents.com/kids/education/home-schooling/homeschooling-101-what-is -homeschooling/>

Ray, B. D., , et al. (2021). HOMESCHOOLING: THE RESEARCH. National Home Education Research Institute (NHERI). Retrieved from https://www.nheri.org/ 
research-facts-on-homeschooling/\#: :text=There\%20are\%20an\%20estimated\% 204.0,children)\%20\%5Bnote $\% 201 \% 5$ D

Ray, B. D., \& Ray, B. D. (2013). Homeschooling Rising Into the Twenty-First Century: Editor's Introduction. Peabody Journal of Education, 88(3), 261-264. Retrieved from https:// www.tandfonline.com/doi/abs/10.1080/0161956X.2013.796822 https://doi.org/ 10.1080/0161956X.2013.796822

SCHOOL, I. H. (2010). Homeschooling in India. [Blog post]. Retrieved from https:// alternativeeducationindia.wordpress.com/2010/07/30/homeschooling-in-india-and -rte-legal-issues/> 